IZADP No. 1027

Labor Mobility, Trade and Social Capital

Maurice Schiff

February 2004 


\title{
Labor Mobility, Trade and Social Capital
}

\author{
Maurice Schiff \\ World Bank and IZA Bonn
}

\section{Discussion Paper No. 1027 \\ February 2004}

\author{
IZA \\ P.O. Box 7240 \\ 53072 Bonn \\ Germany
}

Phone: +49-228-3894-0

Fax: +49-228-3894-180

Email: iza@iza.org

\begin{abstract}
Any opinions expressed here are those of the author(s) and not those of the institute. Research disseminated by IZA may include views on policy, but the institute itself takes no institutional policy positions.

The Institute for the Study of Labor (IZA) in Bonn is a local and virtual international research center and a place of communication between science, politics and business. IZA is an independent nonprofit company supported by Deutsche Post World Net. The center is associated with the University of Bonn and offers a stimulating research environment through its research networks, research support, and visitors and doctoral programs. IZA engages in (i) original and internationally competitive research in all fields of labor economics, (ii) development of policy concepts, and (iii) dissemination of research results and concepts to the interested public.
\end{abstract}

IZA Discussion Papers often represent preliminary work and are circulated to encourage discussion. Citation of such a paper should account for its provisional character. A revised version may be available on the IZA website (www.iza.org) or directly from the author. 
IZA Discussion Paper No. 1027

February 2004

\title{
ABSTRACT
}

\section{Labor Mobility, Trade and Social Capital ${ }^{*}$}

Labor market integration raises welfare in the absence of distortions. This paper examines labor and goods market integration in a general equilibrium model with social capital. The findings are: i) labor market integration has an ambiguous impact on welfare, and raises it if the goods produced and the labor skills are sufficiently different; ii) compared to Pareto optimum, labor mobility (social capital) is excessively large (depleted); iii) trade is superior to labor market integration if trading costs are no higher than private migration costs; otherwise the outcome is ambiguous; and iv) the creation of new institutions in response to labor market integration has an ambiguous impact on welfare.

JEL Classification: F16, F22, J61, Z13

Keywords: $\quad$ social capital, labor market integration, trade

\author{
Maurice Schiff \\ Development Research Group \\ The World Bank \\ Mailstop No. MC3-303 \\ 1818 H. St. NW \\ Washington DC 20433 \\ Tel.: +12024737963 \\ Fax: +1202522 1159 \\ Email: mschiff@worldbank.org
}

\footnotetext{
* I would like to thank Gary Becker and Yoram Weiss for comments on an earlier incarnation of the paper, Subhayu Bandyopadhyay, Carsten Fink, Keiko Kubota, Marcelo Olarreaga, Ignacio Palacios, Howard Shatz, and participants at seminars at Bar-llan University and the World Bank for useful comments, and Alessandro Nicita for excellent assistance with figures and simulations. The views expressed here are mine and do not necessarily reflect those of the World Bank or its affiliated organizations.
} 


\section{Labor Mobility, Trade and Social Capital}

\section{Introduction}

The US has a more integrated labor market than the EU. Assuming this is the only difference between them, what can we say about their relative welfare? Is welfare necessarily higher in the economy with the higher labor mobility? This paper attempts to shed some light on this and related issues.

A basic assumption of the analysis is that individuals are affected by their social environment. Their productivity depends on social capital, which can be defined as "the ability of people to work together for common purposes in groups or organizations (Coleman, 1988) or as "the density of trust existing within a group" (Paldam and Svendsen, 2000). The fact that individuals are affected by their social environment implies that the movement of people differs from the movement of goods. Nevertheless, the welfare consequences of labor and goods market integration in the presence of social capital have not been examined in the literature.

The role of social capital for economic growth and development has been examined in a series of recent papers. Rodrik (1998) studied the impact of social capital on economic growth. He provides econometric evidence that the countries that experienced the sharpest decline in growth after 1975 were those with divided societies, including a high degree of ethnic fragmentation, and with weak institutions of conflict management. Similarly, Collier and Gunning (1999) argue that the slow growth in Africa can be attributed to a high degree of ethnic fragmentation and weak political rights.

Woolcock and Narayan (2000) provide a useful overview of the use of social capital in economics and the implications for policy and research, focusing on local, 
regional and national aspects. Rauch (2001) examines international aspects of social capital. He argues that transnational social or business networks - whose members share a social capital attribute such as belonging to an extended family, region, ethnic or language group - are formed to overcome various costs associated with international trade, such as inadequate information or weak enforcement of international contracts. As shown in Section 3, our model also includes network externalities associated with social capital.

This paper abstracts from production complementarities between migrants and natives. A different view is provided by Borjas (1995) who looks at the effect of immigration on the US. He views migration as generating production complementarities between immigrants and native factors of production, either between labor-including migrants--and native capital, or between skilled natives and unskilled migrants. The assumption of complementarity also underlies Zak, Feng and Kugler's (1998) work on migration, fertility and endogenous growth.

This paper assumes that migration generates negative externalities because of its effect on social capital. Borjas (1995) examines cases of positive externalities of migration, including its effect on market size and productivity in the host country. Migration is also assumed to generate a positive externality in Carrington et al. (1996) by reducing migration costs for subsequent migrants. Welfare implications of migration under endogenous moving costs are examined at the end of Section 5.

Schiff (2002), which examines South-North migration in the presence of social capital, differs in several ways from this paper. First, in Schiff (2002), migration is unidirectional, from the poorer to the richer country. In this paper, migration takes place simultaneously between two similar regions. Second, social capital affects utility in Schiff 
(2002) and productivity in this paper. Third, the nature and number of externalities caused by migration differs in the two papers. Fourth, complementarity between labor and capital is assumed in Schiff (2002) but not here. Finally, the policy recommendations are regionspecific in Schiff (2002) while they apply to all regions in this paper.

The paper is organized as follows. Evidence to support two basic assumptions of the model - that social capital raises productivity and falls with labor mobility-is provided in Section 2. The model is presented in Section 3. The solution in the absence of labor market integration is offered in Section 4. Section 5 presents the labor market integration solution and compares it with the Pareto optimum. Section 6 provides the solution in the absence of negative externalities of labor mobility. Comparisons with the free trade equilibrium are examined in Section 7. Section 8 looks at the impact of an increase in the area of the integrating labor market. Section 9 concludes and presents suggestions for further research. An appendix provides derivations of results.

\section{Empirical Evidence}

The model developed in Section 3 is based on two assumptions, namely, that social capital raises productivity and falls with labor mobility. This section reviews some of the evidence supporting these assumptions. The literature provides two alternative measures of social capital. The first one is the degree of participation in formal civic groups and organizations and in informal networks. The second measure is based on aspects of social trust and norms of cooperative behavior. 
A number of studies have shown that social capital raises social and economic well-being. For instance, Putnam (2000) describes studies showing that more civically active communities in the US-those with higher levels of the first measure of social capital—are more successful in dealing with poverty, unemployment, crime, drug abuse, education and health. And in his celebrated study of civic traditions in Italy, Putnam (1993) shows that the strongest explanatory variable for the quality of local or regional public services is the degree of participation in "horizontal associations" or networks. As for developing countries, Narayan (1997) and Narayan and Pritchett (1999) find that, ceteris paribus, Tanzanian villages with higher levels of social capital—measured in terms of involvement in voluntary associations - have higher incomes.

Turning to the second measure of social capital, Knack and Keefer (1997) find that trust and civic norms result in higher growth. Paldam and Svendsen (2000) also provide examples of the positive link between trust and economic performance. Also, a World Bank (2000) study offers evidence that social capital reduces poverty, risk and conflict. And, as noted earlier, Rodrik (1998) and Collier and Gunning (1999) find that ethnic fragmentation and social conflict reduce growth.

In conclusion, various aspects of social capital have been found to be associated with increased income and growth. What about the link between mobility and social capital?

A higher degree of mobility tends to weaken social ties, and transactions among less familiar agents are likely to result in higher transactions costs (Zak and Knack, 2001). That mobility reduces the level of social capital is also supported by the work of DiPasquale and Glaeser (1998). They show-based on data from the U.S. General Social 
Survey - that homeowners tend to invest more in social capital than renters, and that a large portion of the effect of homeownership on these investments in social capital is likely to be due to the lower mobility of homeowners. Similar results are obtained by Glaeser et al. (2001) who also find that social connections fall sharply with distance. ${ }^{1}$ Similarly, Putnam (2000) argues that residential stability is associated with greater civic engagement, while mobility uproots people and reduces civic participation. $^{2}$

This paper develops a parsimonious general equilibrium model in order to examine the link between labor market and goods market integration, social capital and welfare. Based on the evidence presented in this section, social capital is assumed to raise productivity and fall with labor mobility.

\section{The Model}

The objective of this paper is not to examine the impact of an increase in unidirectional migration from poorer to richer (South-North or rural-urban) areas. Rather, it is to study the effect of an increase in generalized labor mobility across regions with similar incomes. In this model, labor moves not because of regional income differences but because the supply of skills is unevenly distributed over space. This seems reasonable for a country like the U.S. where many industries are concentrated spatially, ${ }^{3}$ and where labor

\footnotetext{
1 Data for the mid-1980s show that with about $20 \%$ of U.S. households moving on average annually, $35 \%$ of those in renter-occupied units moved while about $9 \%$ of those in owner-occupied units did. For the late $1990 \mathrm{~s}, 33 \%$ (8\%) of those in renter-occupied (owner-occupied) housing moved. The ratio has thus been stable over time, with renters 4 times more mobile than owners. On other determinants of labor mobility in the US, including education and age, see Wildasin (2000, pp. 74-75) and references therein.

2 As Fannie Mae - which provides liquidity by creating a secondary market for mortgages - advertises "Neighborhoods are stronger when families are able to own their own homes."

3 Spatially concentrated industries include the computer industry in Silicon Valley and the Washington, D.C. area, aerospace in Southern California and Washington State, automobiles in the Midwest, movies in Hollywood, finance in New York city, and textiles in the South.
} 
movements are typically associated with local or regional demand shocks for specific skills. These aspects are captured in the model presented below.

Assume two "islands" $\mathrm{i}=1,2$. Two-way migration can be obtained by assuming different endowments of industry-specific skills in each island, low cross-island moving costs for labor and prohibitive moving costs for goods. The assumption on relative moving costs of labor and goods is reversed in Section 7.

Assume that the initial population on each island is $n=1$. Denote by $n_{i j}$ the proportion of natives of Island $i$ living on Island $j(i, j=1,2)$. Before migration takes place, $\mathrm{n}_{11}=\mathrm{n}_{22}=1$, and the proportion that migrates $\mathrm{m}=\mathrm{n}_{12}=\mathrm{n}_{21}=0$.

Each native of Island $\mathrm{i}$ living on Island $\mathrm{j}, \mathrm{I}_{\mathrm{ij}}$, consumes $\mathrm{H}_{\mathrm{ij}}$ and $\mathrm{h}_{\mathrm{ij}}$ units of goods $\mathrm{H}$ and $\mathrm{h}$, with utility given by

$$
U_{i j}=H_{i j}{ }^{\beta}+h_{i j}{ }^{\beta}, \quad \beta<1,
$$

where the parameter $\beta$ reflects the degree to which marginal utility diminishes as consumption of $\mathrm{H}$ and $\mathrm{h}$ rises. As $\beta$ increases, marginal utility declines more slowly and $\mathrm{H}$ and $\mathrm{h}$ become closer substitutes, and are perfect substitutes when $\beta=1$.

Output of $\mathrm{H}$ and $\mathrm{h}$ depend on human capital and on local public goods and services whose provision - based on the evidence provided in Section 2 - is positively related to the level of social capital. Alternatively, assume that output depends on human capital and on aspects of social capital such as the extent of trust and cooperation among individuals (see Section 2). Thus, $\mathrm{H}(\mathrm{h})$ is produced with human capital or skill $\mathrm{K}(\mathrm{k})$ and social capital S. Islands 1 and 2 are symmetric, except that natives of Island 1 (2) are endowed 
with skill $\mathrm{K}(\mathrm{k})$ and produce $\mathrm{H}(\mathrm{h}){ }^{4}$ The production functions for $\mathrm{H}$ and $\mathrm{h}$ are $\mathrm{H}_{1 \mathrm{j}}=\mathrm{H}(\mathrm{K}$, $\left.\mathrm{S}_{1 \mathrm{j}}\right)$ and $\mathrm{h}_{2 \mathrm{j}}=\mathrm{h}\left(\mathrm{k}, \mathrm{S}_{2 \mathrm{j}}\right)$, where $\mathrm{S}_{\mathrm{ij}}$ is the social capital available to individual $\mathrm{I}_{\mathrm{ij}}$. Specifically,

$$
H_{1 j}=K^{*} S_{1 j}, h_{2 j}=k * S_{2 j} ; j=1,2
$$

Following Lazear (1997), assume that the social capital $S_{\mathrm{ii}}$ of individual $\mathrm{I}_{\mathrm{ii}}$ is characterized by 'network' externalities (as with language), i.e., it increases with the proportion $\mathrm{n}_{\mathrm{ii}}$ of natives in the total population of island $\mathrm{i}$, or equivalently, it declines with the proportion $\mathrm{m}=1-\mathrm{n}_{\mathrm{ii}}$ of migrants in the total population. In other words, and as the evidence in Section 2 has shown, the lower the degree of mobility (m) of the population, the higher the level of social capital because the proportion of those who have interacted for a long period of time and have established cooperative relations and trust is higher. This is also supported by Durkin (1998) who argues that positive spillovers from a groupspecific public good rise with the share of that group in the population. Specifically, assume that the level of social capital available to each native $\mathrm{I}_{\mathrm{ii}}$ is equal to the number of potential relations with other natives, i.e., $\mathrm{S}_{\mathrm{ii}}=\mathrm{n}_{\mathrm{ii}}{ }^{5}$

An individual $I_{i j}$ moving from Island $i$ to Island $j$ does not benefit from the same amount of social capital as natives of Island $\mathrm{j}$ because creating a network of social relations and building trust takes time, and some relations and experiences (e.g., those with family and childhood friends) cannot be recreated. Also, natives of Island i may speak a different language than those in Island j. The islands may also differ in other aspects, including ethnicity and race. Glaeser et al. (2000) examined determinants of trust and trustworthiness in an experiment with 258 Harvard undergraduates and found that

\footnotetext{
${ }^{4}$ For simplicity, the paper assumes one skill per island. The qualitative results hold if each island is endowed with both skills, as long as the skills ratios differ enough across the islands so that the wage rate difference in the absence of migration is greater than private migration costs.

${ }^{5}$ The number of potential relations for each individual is $n_{\mathrm{ii}}$ if $\mathrm{n}_{\mathrm{ii}}$ is continuous and $\left(\mathrm{n}_{\mathrm{ii}}-1\right)$ if $\mathrm{n}_{\mathrm{ii}}$ is discrete.
} 
differences in nationality and race reduce the level of trustworthiness. Hence, migrants are assumed to gain partial access to the social capital available in their island of destination. Specifically, the social capital $S_{i j}$ available to a migrant from Island $i$ to Island $j(i \neq j)$ is $\mathrm{S}_{\mathrm{ij}}=\alpha \cdot \mathrm{n}_{\mathrm{jj}}, \alpha \leq 1 .^{6}$ For instance, if the language spoken on island $\mathrm{i}$ differs from that on island $\mathrm{j}, \alpha$ measures the degree of similarity between the two languages. We thus have:

$$
S_{i j}=\alpha^{1-\delta_{i j}} n_{j j}, 0<\alpha \leq 1 ; i, j=1,2,
$$

where $\delta_{i j}=1$ for natives $(i=j)$ and $\delta_{i j}=0$ for migrants $(i \neq j)$.

Without loss of generality, assume $\mathrm{K}=\mathrm{k}=1$ before migration takes place. Further, assume that migration entails real resource costs (e.g., goods, time and/or depreciation of skills), and that an emigrant leaving Island $i$ with 1 unit of skills arrives in Island $j$ with $\gamma$ units, where $0<\gamma \leq 1$. Consequently, migrants' productive efficiency falls to a proportion $\varepsilon \equiv \alpha \gamma \leq 1$ of its original value, with the loss $(1-\varepsilon)$ due to real migration costs and private social capital loss.

Given these assumptions and equations (2) and (3), individual output is:

$$
H_{11}=n_{11} ; h_{22}=n_{22} ; H_{12}=\varepsilon n_{22} ; h_{21}=\varepsilon n_{11} \text {. }
$$

\section{No Labor Market Integration}

In the absence of migration, $\mathrm{i}=\mathrm{j}$. Due to prohibitive transport costs for goods, $\mathrm{H}$ and $\mathrm{h}$ are not traded. Thus, quantities consumed equal quantities produced. From equation

\footnotetext{
${ }^{6}$ A migrant from Island $\mathrm{i}$ to Island $\mathrm{j}$ might also benefit from the presence on Island $\mathrm{j}$ of other migrants from Island $\mathrm{i}$. Thus, migration would entail positive externalities for the other migrants on Island $\mathrm{j}$, as well as negative externalities on the natives of Island i. I abstract here from these positive externalities because they complicate the model without affecting the results. The reason is that, under symmetry and positive migration costs, the number of migrants is always smaller than the number of natives, so that the negative externalities always dominate the positive ones.
} 
(4), these are $\mathrm{H}_{11}=\mathrm{n}_{11}=1, \mathrm{~h}_{22}=\mathrm{n}_{22}=1$ and $\mathrm{H}_{22}=\mathrm{h}_{11}=0$. From equation (1), utility is $\mathrm{U}_{11}$

$=\mathrm{U}_{22}=1$. The relative value of $\mathrm{H}$ (in units of $\mathrm{h}$ ) on island $\mathrm{i}, \mathrm{P}_{\mathrm{i}}$, equals the ratio of marginal utilities, which-from equation (1)-is: $\mathrm{P}_{\mathrm{i}} \equiv\left(\mathrm{h}_{\mathrm{ii}} / \mathrm{H}_{\mathrm{ii}}\right)^{1-\beta}$. The natives of Island 1 (2) consume no $h(H)$. Thus, $P_{1}=0$ and $P_{2}=\infty$, and there is an incentive to migrate in both directions.

\section{Labor Market Integration}

Assume now that the two islands sign a treaty integrating their labor markets by allowing free movement of people between them. As long as the migration benefits are larger than their private costs — which is the case with finite migration costs since $\mathrm{P}_{1}=0$ and $\mathrm{P}_{2}=\infty$-people from Island 1 (2) will take their skills $\mathrm{K}(\mathrm{k})$ to Island 2 (1) in order to produce $H(h)$ there and exchange part of it for $h(H)$. Because people migrate in both directions, goods $\mathrm{H}$ and $\mathrm{h}$ are now available on both islands.

Migration has three effects on welfare. First, since both $\mathrm{H}$ and $\mathrm{h}$ are now produced and consumed on both islands, everyone benefits from diversification of consumption. On the other hand, migration leads to a private loss of productive skills due to real migration costs and private loss of social capital. And third, migration generates negative externalities which lower social capital. The implications of the latter effect have not been examined in the literature.

Natives from Island $\mathrm{i}$ maximize $U_{\mathrm{ij}}$. This includes choosing the value of $\mathrm{j}$, that is $\mathrm{j}$ $\neq \mathrm{i}$ (migrating) or $\mathrm{j}=\mathrm{i}$ (not migrating). Given symmetry, we focus on Island 1 . There are nine equations and nine variables. The variables are: $\mathrm{n}_{11}, \mathrm{~m}, \mathrm{~S}_{11}, \mathrm{~S}_{21}, \mathrm{P}_{1}, \mathrm{H}_{11}, \mathrm{~h}_{11}, \mathrm{H}_{21}$ and $\mathrm{h}_{21}$. The equations are: 
Population identity:

(i) $n_{11}+m=1$

Budget constraint of natives $\mathrm{I}_{11}$ :

(ii) $P_{l}\left(n_{11}-H_{11}\right)=h_{11}$

Budget constraint of migrants $\mathrm{I}_{21}$ :

(iii) $\varepsilon n_{11}-h_{21}=P_{1} H_{21}$

Market clearing: ${ }^{7}$

(iv) $n_{11}\left(n_{11}-H_{11}\right)=m H_{21}$

(iv') $m\left(\varepsilon n_{11}-h_{21}\right)=n_{11} h_{11}$

First Order Conditions:

(v) $P_{1}=\left(h_{11} / H_{11}\right)^{1-\beta}$

(vi) $P_{1}=\left(h_{21} / H_{21}\right)^{1-\beta}$

Migration Equilibrium:

$U_{11}=U_{12}=U_{21}$ (symmetry) or

(vii) $H_{11}^{\beta}+h_{11}^{\beta}=H_{21}^{\beta}+h_{21}^{\beta}$.

Social Capital:

(viii) $S_{11}=n_{11}$

(ix) $S_{21}=\alpha n_{11}$

The solution to the system of equations (i)-(ix) is given below and the derivation is provided in Schiff (1999). The equilibrium number of natives $n_{11}$ and of migrants $m$ is

$$
\begin{aligned}
& n_{11}=\frac{\varepsilon^{\frac{\beta}{\beta-1}}}{1+\varepsilon^{\frac{\beta}{\beta-1}}}, \\
& m=\frac{1}{1+\varepsilon^{\frac{\beta}{\beta-1}}} .
\end{aligned}
$$

From equation (6), it follows that $\partial \mathrm{m} / \partial \varepsilon>0$ : migration falls as private migration costs increase, including increases in the private loss of social capital (1- $\alpha)$, say, due to greater differences in social capital across countries or regions. Similarly, Cashin and Sahay (1996) hypothesize that the relatively greater contribution of cross-regional migration to income convergence in the US, in comparison with that found for regions of

\footnotetext{
${ }^{7}$ Equation (iv') is not independent of equations (ii), (iii) and (iv) (Walras Law).
} 
Europe and India, may be due to relatively greater linguistic, social and cultural uniformity in the US (a higher value for $\varepsilon$ ) promoting relatively larger cross-regional labor flows. $^{8}$

Since $\varepsilon \leq 1$ and $\beta<1$, it follows from equations (5) and (6) that $\mathrm{n}_{11} \geq \mathrm{m}$, i.e., no more than half the population of each island migrates. Thus, whenever labor market integration between two islands with same population size and income involves private migration costs (either physical or in terms of social capital), natives remain a majority. If migration takes place between more than two islands, natives can become a minority but, as shown in Section 8, they remain a plurality.

The relative price of $\mathrm{H}$ (in units of $\mathrm{h}$ ) is

$$
P_{1}=\varepsilon \leq 1 .
$$

That $\mathrm{P}_{1} \leq 1$ on Island 1 is due to the fact that when $\varepsilon<1$, the supply of $\mathrm{H}$ is larger than the supply of $h$, both because $n_{11}>m$ (equations (5) and (6)) and because migrants experience a private loss of productive skills, so $P_{1}<1$. And when $\varepsilon=1, \mathrm{n}_{11}=\mathrm{m}=1 / 2, \mathrm{H}=$ $\mathrm{h}$, and $\mathrm{P}_{1}=1$.

Consumption and utility are

$$
\begin{aligned}
& H_{11}=H_{21}=\left(\varepsilon^{\frac{\beta}{\beta-1}} /\left(1+\varepsilon^{\frac{\beta}{\beta-1}}\right)\right)^{2} \\
& h_{11}=h_{21}=\varepsilon^{\frac{2 \beta-1}{\beta-1}} /\left(1+\varepsilon^{\frac{\beta}{\beta-1}}\right)^{2} \\
& U_{11}=U_{21}=H_{11}^{\beta}+h_{11}^{\beta}=\left(\varepsilon^{\frac{2 \beta^{2}}{\beta-1}}+\varepsilon^{\frac{2 \beta^{2}-\beta}{\beta-1}}\right) /\left(1+\varepsilon^{\frac{\beta}{\beta-1}}\right)^{2 \beta}
\end{aligned}
$$

\footnotetext{
${ }^{8}$ Neither Cashin and Sahay (1996) nor Barro and Sala-I-Martin (1992) find that intra-regional labor flows are an important explanatory of cross-regional income convergence.
} 
Note for later use that, from equations (5), (8), (9) and (10), $\mathrm{H}_{11}=\mathrm{n}_{11}^{2}$ (equation $\left.8^{\prime}\right), \mathrm{h}_{11}=\varepsilon^{1 /(1-\beta)} \mathrm{n}_{11}{ }^{2}=\varepsilon^{1 /(1-\beta)} \mathrm{H}_{11} \leq \mathrm{H}_{11}$ (equation 9'), and $\mathrm{U}_{11}=\left(1+\varepsilon^{\beta /(1-\beta)}\right) \mathrm{n}_{11}{ }^{2 \beta}$ (equation $\left.10^{\prime}\right)$.

We can now define the boundaries of the parameter space for which welfare rises, falls or remains unchanged. From equation (10), it is clear that under labor market integration utility depends exclusively on parameters $\varepsilon$ and $\beta$. Given symmetry and migration arbitrage, utility $U$ is the same for all groups. Recall that in the absence of migration, $U=1$. The parameter space $(\varepsilon, \beta)$ for which $U=1$ (the ' $U=1$ ' contour) under labor market integration is shown in Figure 1. From equation (10), the contour ' $U=1$ ' takes the shape of a horizontal line at $\beta=1 / 2$. Thus, there are no gains or losses from migration when $\beta=1 / 2$, no matter what the private migration costs $(1-\varepsilon)$ are.

\section{[FIGURE 1 ABOUT HERE]}

From equation (10), $U \gtreqless 1$ when $\beta \lesseqgtr 1 / 2$. This is shown in Figure 1 where $U>1$ for $\beta<1 / 2$ and increases as $\beta$ falls. Thus, labor market integration is beneficial for low values of $\beta$ where marginal utility diminishes rapidly and the benefits of diversification are large. For instance, utility increases from $U=1$ for $\beta=1 / 2$ to $U=2$ for $\beta=0$. On the other hand, $U<1$ when $\beta>1 / 2$. Thus, labor market integration is immiserizing - the value of the migration opportunity is negative — when $\beta$ is large. ${ }^{9}$

The fact that welfare increases for low values of $\beta$ and decreases for high values of $\beta$ can be given an alternative interpretation. From equation (1), if $\beta=1$, both marginal

\footnotetext{
${ }^{9}$ As is shown in Figure 1, the monotonic relationship between $\beta$ and $U$ when $\beta<1 / 2$ does not hold for $\beta>1 / 2$. The reason is that an increase in $\beta$ raises welfare at the initial migration level but the resulting migration increase raises welfare when $\beta<1 / 2$ and lowers it when $\beta>1 / 2$. Thus, welfare may take the same value for different values of $\beta$ when $\beta>1 / 2$.
} 
utilities are equal to $1, \mathrm{H}$ and $\mathrm{h}$ are perfect substitutes, and there is no gain from diversification. The greater the difference in marginal utilities of $\mathrm{H}$ and $\mathrm{h}$, the greater the benefit of diversification. The ratio of marginal utilities $U_{H} / U_{h}=(h / H)^{1-\beta}$. Recall that when $\varepsilon<1, \mathrm{H}>\mathrm{h}$, and as long as $\beta<1, \mathrm{U}_{\mathrm{H}} / \mathrm{U}_{\mathrm{h}}<1$. Then, $\partial\left(\mathrm{U}_{\mathrm{H}} / \mathrm{U}_{\mathrm{h}}\right) / \partial \beta>0$. Thus, as $\beta$ falls, $\mathrm{U}_{\mathrm{H}} / \mathrm{U}_{\mathrm{h}}$ falls, the difference between the marginal utilities of $\mathrm{H}$ and $\mathrm{h}$ increases, and the benefits of diversification increase.

The welfare gain from migration is larger when $\beta$ is smaller, i.e., as the degree of substitution between $\mathrm{H}$ and $\mathrm{h}$ is lower. A low degree of substitution between $\mathrm{H}$ and $\mathrm{h}$ implies a low degree of substitution between inputs $\mathrm{K}$ and $\mathrm{k}$. Thus, if integration is between two "islands" or countries with similar labor endowments (with skills K similar to $\mathrm{k}$ ), the gains from diversification are likely to be small. If the countries have different types of labor producing different types of goods, labor market integration is more likely to generate welfare gains.

The result that labor market integration is beneficial for $\beta>1 / 2$ and immiserizing for $\beta<1 / 2$ holds for marginal increases in labor market integration as well. From equation (10), $\partial \mathrm{U} / \partial \varepsilon \gtreqless 0$ for $\beta \lesseqgtr 1 / 2$. This is shown in Figure 1 . Thus, for $\beta<1 / 2, \mathrm{U}>1$, and the benefits of migration rise as $\varepsilon$ increases and the private migration costs $(1-\varepsilon)$ fall. For instance, as shown in Figure 1 , for $\beta=.2$, $\mathrm{U}$ rises from 1.23 for $\varepsilon=.05$ to 1.32 for $\varepsilon=.25$. For $\beta>1 / 2, U<1$, and $\partial U / \partial \varepsilon<0$. As shown in Figure 1 , when $\beta=.8$, $U$ falls from .97 for $\varepsilon=.3$ to .88 for $\varepsilon=.7$ to .79 for $\varepsilon=.9$. Thus, the welfare impact of migration increases in absolute value as private migration costs $(1-\varepsilon)$ fall. 
As noted earlier, Cashin and Sahay (1996) hypothesized that the greater labor response to an income differential or greater labor mobility in the US than in Europe was due to the higher mobility cost in the latter. Assuming that mobility costs are the only difference between the two regions, lower mobility costs in the US (higher $\varepsilon$ ) imply higher welfare than in Europe if diversification benefits are high $(\beta<1 / 2)$. Otherwise $(\beta>1 / 2)$, the US is worse off. Thus, though the US labor market is more integrated than the European one, its impact on welfare is ambiguous.

Labor mobility is excessive compared to the Pareto optimum. Though the Pareto optimum cannot be solved analytically, numerical solutions can be obtained. (The Pareto optimum migration level $\mathrm{m}$ is the solution of $\left.\varepsilon^{\beta}(1-2 \mathrm{~m})=2(1-\mathrm{m})^{\beta} \mathrm{m}^{1-\beta}\right)$. Recalling that $\varepsilon$ and $\beta$ vary between 0 and 1 , the Pareto optimum solution was simulated for values of $\varepsilon$ and $\beta$ ranging from .01 to .99 , in increments of .01 . Average mobility $\mathrm{m}$ was found to be about $30 \%$ in equilibrium and less than $10 \%$ at the Pareto optimum, with an average welfare gain of less than $10 \%$ in equilibrium and close to $20 \%$ at the Pareto optimum.

Alternatively, we assumed that $\varepsilon$ and $\beta$ were normally distributed around $\varepsilon=\beta=$ .5 , with various standard deviations, and calculated averages for the same values of $\varepsilon$ and $\beta$ as before (from .01 to .99) but with the weights given by the density functions. Finally, we simulated the results by assuming $0<\varepsilon<.5$, thereby restricting the level of migration costs. These different simulations have no appreciable impact on the difference between market equilibrium and Pareto optimum results. Migration remains about three times smaller, and the welfare gain more than twice larger, at the Pareto optimum than at the equilibrium. Thus, the difference between the market equilibrium and the social optimum seems quantitatively important. 
What can the authorities do to raise welfare? A tax on mobility is unacceptable in democratic societies where freedom of movement is a fundamental right. An alternative is to subsidize length of residence. DiPasquale and Glaeser (1999) and Putnam (2000) find that homeowners invest more than renters in their neighborhood (in terms of civic engagement, care of their homes, interaction with neighbors, beautification of public areas, and crime prevention). A subsidy on home ownership would thus help build social capital. This is the case in the U.S. where interest payments on mortgages are tax deductible. Another measure would be to make the capital gains tax on the sale of a house a declining function of the length of time of residence.

With the increased labor mobility associated with labor market integration, new institutions are likely to emerge in response to a greater demand for reducing migration costs (higher $\gamma$ ) and private social capital losses (higher $\alpha$ ). Costless institutional changes that lower migration costs raise welfare for $\beta<1 / 2$, lower it for $\beta>1 / 2$, and leave it unchanged for $\beta=1 / 2$. Examples include the elimination of visa and work permit requirements for EU citizens, and mutual recognition of professional degrees (Wildasin, 2000, p. 76). In fact, such reforms might lower administrative costs, in which case welfare might also rise for $\beta=1 / 2$. In the case of a costly institutional reform, if authorities charge a fee such that mobility costs are unchanged, then mobility remains unchanged (abstracting from income effects), and welfare rises (falls) if fee revenues are larger (smaller) than the cost of the reform.

The welfare impact of migration is different if moving costs decline with the number of migrants in the host country (Carrington et al., 1996). Assume that moving costs are unchanged for $\mathrm{m}=0$ and decline as $\mathrm{m}$ increases, i.e., $\varepsilon=\varepsilon(\mathrm{m})$, with $\varepsilon^{\prime}<0$. This 
has two effects on welfare. First, welfare rises with the reduction in moving costs. Second, the increase in $\varepsilon$ raises equilibrium migration (equation (6)) and affects welfare. From equation (10), $\partial \mathrm{U} / \partial \varepsilon \gtreqless 0$ for $\beta \lesseqgtr 1 / 2$. Consequently, if moving costs decline with the number of migrants, labor mobility raises welfare for $\beta \leq 1 / 2$ and the effect is ambiguous for $\beta>1 / 2$.

\section{Labor Market Integration in the Absence of Externalities}

Examining the equilibrium in the absence of externalities enables us to assess their impact and is helpful in characterizing the equilibrium under free trade in Section 7. An absence of externalities associated with migration can occur if people in both "islands" are identical in terms of the attributes of social capital. For instance, if the only characteristic that matters is the identity of the 'club' one belongs to, including a church, social club or sports club, two-way migration by people belonging to the same club has no impact on social capital.

In that case, there is no private loss of social capital from migration $(\alpha=1)$, and the social capital of natives is not affected by two-way migration and is equal to 1 rather than (1-m). Then, equation (4) becomes $\mathrm{H}_{11}=\mathrm{H}_{12}=\mathrm{h}_{21}=\mathrm{h}_{22}=1$. Substituting in equations (i) to (vii), and denoting the "no externality" case by the superscript " $N$ ", we obtain: $\mathrm{n}_{11}{ }^{\mathrm{N}}=$ $\gamma^{\beta /(1-\beta)} /\left(1+\gamma^{\beta /(1-\beta)}\right)<\mathrm{n}_{11}, \mathrm{~m}^{\mathrm{N}}=1 /\left(1+\gamma^{\beta /(1-\beta)}\right)>\mathrm{m}, \mathrm{H}_{11}{ }^{\mathrm{N}}=\mathrm{n}_{11}{ }^{\mathrm{N}}, \mathrm{h}_{11}{ }^{\mathrm{N}}=\gamma^{1 /(1-\beta)} \mathrm{n}_{11}{ }^{\mathrm{N}}$, and $\mathrm{U}^{\mathrm{N}}=$ $\left(\mathrm{n}_{11}{ }^{\mathrm{N}}\right)^{\beta}\left(1+\gamma^{\beta /(1-\beta)}\right)>\mathrm{U} .{ }^{10}$ For comparison, the solution in the case of negative externalities

\footnotetext{
${ }^{10}$ Note that $\mathrm{h}^{\mathrm{N}}>\mathrm{h}$ because there are more migrants and their productivity is higher, while the impact on $\mathrm{H}^{\mathrm{N}}$ is ambiguous because there are fewer but more productive natives.
} 
is shown in equations (5), (6), (8'), (9') and (10'). For instance, note that $\mathrm{H}_{11}{ }^{\mathrm{N}}=\mathrm{n}_{11}{ }^{\mathrm{N}}$ while $\mathrm{H}_{11}=\mathrm{n}_{11}^{2}$.

For example, assume $\varepsilon=\beta=1 / 2$. Since $\alpha=1, \gamma=1 / 2$. For $\beta=1 / 2$, welfare $U=1$ in the presence of externalities, and $n_{11}=2 / 3, m=1 / 3, H=4 / 9$ and $h=1 / 9$. In the absence of externalities, $\mathrm{n}_{11}{ }^{\mathrm{N}}=\mathrm{m}^{\mathrm{N}}=1 / 2, \mathrm{H}^{\mathrm{N}}=\mathrm{h}^{\mathrm{N}}=1 / 2$, and $\mathrm{U}^{\mathrm{N}}=1.41$. Thus, for these parameter values, the externalities result in a reduction of $11 \%$ in the consumption of $\mathrm{H}$ (from $1 / 2$ to $4 / 9$ ), $78 \%$ in the consumption of $\mathrm{h}$ (from $1 / 2$ to $1 / 9$ ), and $29 \%$ in welfare (from 1.41 to 1 ).

\section{Equilibrium under free trade}

Mundell (1957) has shown the equivalence between the movement of goods and the movement of factors. On the other hand, a number of politicians and economists in the US and the EU who tend to support free trade also advocate restrictions on migration. Bhagwati (1991, p.3) argues that this inconsistency is due to a lack of consistent criteria by which the two issues are judged, and that applying the utilitarian logic leads to the free migration solution (pp. 5-6). As we have shown, this need not hold in the presence of social capital: free migration is not optimal and may result in a welfare loss.

So far, we assumed that, due to prohibitive transport costs, $\mathrm{H}$ and $\mathrm{h}$ are not traded. Assume now that the physical cost of moving goods $\mathrm{H}$ and $\mathrm{h}$ is equal to the real resource cost $(1-\gamma)$ of moving people. Since migration entails a private loss of social capital while trade does not, trade takes place. ${ }^{11}$ Then, consumption and welfare are the same as in the migration case where there is no private social capital loss and no externalities of

\footnotetext{
11 In our model, trade and migration are substitutes: either labor or goods move-depending on which private moving costs are lower-but not both. Trade and migration are also substitutes in the HeckscherOhlin model. On the other hand, Markusen (1983) obtains complementarity by amending different features
} 
migration. The solution, given in Section 6, is $U^{\mathrm{FT}}=\left(\mathrm{n}_{11}{ }^{\mathrm{N}}\right)^{\beta}\left(1+\gamma^{\beta /(1-\beta)}\right)=\mathrm{U}^{\mathrm{N}}$, where 'FT' stands for 'free trade', with $\mathrm{U}^{\mathrm{FT}}>\mathrm{U}^{12}$

For instance, assume that both transport costs and private real migration costs are zero, i.e., $\gamma=1$. Then, under free trade, goods and factor prices are equalized across islands and there is no incentive to migrate. Given symmetry, people on island 1 (2) produce one unit of $\mathrm{H}(\mathrm{h})$ and export half of it for half a unit of $\mathrm{h}(\mathrm{H})$. Thus, everyone consumes half a unit of $\mathrm{H}$ and $\mathrm{h}$, and welfare is $\mathrm{U}^{\mathrm{FT}}=2 / 2^{\beta}>1$. For $\beta=1 / 2, \mathrm{U}^{\mathrm{FT}}=1.41$. Under labor market integration, $U=1$ when $\beta=1 / 2$ (for any value of $\alpha>0$ ). Thus, for these parameter values, welfare is $41 \%$ higher under free trade than under free migration. Both $U^{\mathrm{FT}}$ and $U$ fall with $\beta$, and so does the difference between them. For instance, for $\beta=$ $1, \mathrm{H}$ and $\mathrm{h}$ are perfect substitutes, migration and trade equal zero, and $\mathrm{U}^{\mathrm{FT}}=\mathrm{U}=1$.

As long as transport costs are lower than private migration costs $(1-\varepsilon)$, including both real resource costs and social capital costs, trade takes place and is superior to migration. If transport costs are higher than (1-e), migration takes place. Whether integration of the labor market or the goods market is superior is ambiguous in this case because private trading costs are higher than private migration costs but they do not entail negative externalities.

Thus, as long as trading costs are lower than private migration costs (including the private loss of social capital), trade takes place and is superior to labor market integration because migration entails a negative externality while trade does not. In that case, a policy

of the Heckscher-Ohlin model, while Lopez and Schiff (1998) obtain complementarity for unskilled labor and substitution for skilled labor in a model with migration costs and financing constraints.

12 If there are also positive externalities in production from migration, then whether utility under free trade or free migration is higher is ambiguous in general. However, see footnote 6 for a case of positive externalities where negative externalities of migration dominate and utility under free trade is higher. 
of trade liberalization is more beneficial than a policy aiming to integrate labor markets. The former raises welfare while the effect of the latter is ambiguous. On the other hand, if trading costs are higher than private migration costs, than migration takes place and whether this is superior to trade is ambiguous.

\section{Increasing the migration area}

Assume that instead of two "islands," there are fifty "states". People in each state produce a state-specific good using a specific skill and state-specific social capital. The fifty goods enter symmetrically in everybody's utility function which is the same for all and is now $\mathrm{U}_{\mathrm{ij}}=\Sigma_{\mathrm{r}}\left(\mathrm{H}_{\mathrm{ijr}}\right)^{\beta}$, where $\mathrm{r}=1, \ldots, 50$ represents the 50 goods. Assume the 50 states now allow free movement of people. This results in a much larger proportion of people migrating than in the two-island case because there are now 49 other states where the returns to one's skills are higher and it takes larger amounts of migration to arbitrage away the private migration benefits.

For instance, as shown in equations (5) and (6), in the two-island case, if there are no private migration costs $(\varepsilon=1)$, then $\mathrm{n}_{11}=\mathrm{n}_{22}=\mathrm{m}=1 / 2$; that is, $50 \%$ of the people remain on their own island and social capital is reduced by half. However, if the same conditions prevail in the case of 50 states, then $\mathrm{n}_{\mathrm{ii}}=1 / 50$ and $\mathrm{m}=49 / 50$; that is, only $2 \%$ of people remain in their own state, $98 \%$ move - with $n_{i i}=n_{i j} ; i \neq j=1, \ldots, 50$-and social capital is reduced by $98 \%$. If there are private migration costs $(\varepsilon<1)$, natives remain a plurality, i.e., $n_{i i}>n_{i j} ; i \neq j=1, \ldots, 50$.

Thus, people are more mobile, and social capital is depleted to a larger degree, in a large country than in a small one. The problem of excessive mobility and excessive 
reduction in social capital exists in small countries as well but is likely to be more pronounced in larger countries such as the United States, China, Brazil or Russia. The problem would be expected to be most severe in the United States as it constitutes the largest and most fully integrated labor market. The issue is also likely to become more pressing in China with the dramatic recent increase in labor mobility, and in Europe due to EU enlargement and deeper factor market integration (EC-92).

\section{Concluding Comments}

This paper has provided a parsimonious general equilibrium model in order to examine the relationship between labor and goods market integration, social capital and welfare. We find that labor market integration results in excessive labor mobility, excessive depletion of social capital, and an ambiguous impact on welfare. This may be particularly important for large and highly integrated labor markets such as that of the United States, and also has implications for the integration of other labor markets, including that of the EU.

A positive welfare impact of labor market integration is more likely, the greater the gains from diversification, i.e., the greater the difference in the goods produced and in the labor skills of the integrating countries or regions. As long as trading costs are lower than private migration costs (including the private loss of social capital), trade takes place and is superior to migration. Otherwise, migration takes place and whether or not it is superior to trade is ambiguous.

The analysis can be extended in several directions. First, a dynamic version of the model, where social capital has to be produced and where its cost—which depends on past consumption of social capital—rises with mobility, and where the present value of 
benefits declines with mobility, would reinforce the results presented here. Second, we briefly examined the impact of changes in institutions that affect migration costs. Institutions that affect the nature of social capital may also respond to exogenous changes in mobility costs. For instance, a more mobile society may create national rather than local institutions - including churches, social clubs, sports clubs, and hotel and restaurant chains — which reduce the loss of social capital associated with mobility. These issues will be examined in future work. 


\section{References}

Barro, R. J. And X. Sala-i-Martin. 1992. "Regional Growth and Migration: A Lapan-United States Comparison." Journal of the Japanese and International Economies 6: 312-346.

Bhagwati, J. 1991. "Free Traders and Free Immigrationists: Strangers or Friends?" Working Paper \# 20 (April), Russell Sage Foundation, N.Y.

Borjas, G. 1995. "The Economic Benefits from Immigration.” Journal of Economic Perspectives 9 (2): 3-22.

Carrington, W.J., E. Detragiache and T. Vishwanath. 1996. "Migration with Endogenous Moving Costs." American Economic Review 86 (4): 909-930.

Cashin, P. and R. Sahay. 1996. "Internal Migration, Center-State Grants, and Economic Growth in the States of India." IMF Staff Papers 43 (1): 123-71.

Coleman, J.S. 1988. "Social capital in the creation of human capital." American Journal of Sociology 94 (Supplement): S95-S120.

Collier, P. and J. W. Gunning. 1999. "Explaining African Economic Performance." Journal of Economic Literature 37 (1): 64-111.

DiPasquale, D. and E.L. Glaeser. 1998. "Incentives and Social Capital: Are Homeowners Better Citizens?" Journal of Urban Economics 45 (2): 354-84.

Durkin, J.T. 1998. "Immigration, assimilation and growth." Journal of Population Economics 11: 273-91.

Glaeser, E. L., D. Laibson, J.A. Scheinkman and C.L. Soutter. 2000. "Measuring Trust.” Quarterly Journal of Economics. (August).

and B. Sacerdote. 2001. "The Economic Approach to Social Capital." NBER Working Paper No. 7728 (March).

Knack, S. and P. Keefer. 1997. "Does Social Capital Have an Economic Payoff? A Cross-Country Investigation.” Quarterly Journal of Economics CXII: 1251-88.

Lazear, E.P. 2000. "Culture and Language." In Essays in Honor of Gary S. Becker. Journal of Political Economy 107 (6): S95-126. Part 2.

Lopez, R. and M. Schiff. 1998. "Migration and the Skill Composition of the Labour Force: The Impact of Trade Liberalization in LDCs," Canadian Journal of Economics 31 (2): 318-36.

Markusen, J.R. 1983. "Factor Movements and Commodity Trade as Complements." Journal of International Economics 14: 341-56.

Mundell, R. 1957. "International Trade and Factor Mobility," American Economic Review XLVII (June):321-335. 
Narayan, D. 1997. "Voices of the Poor: Poverty and Social Capital in Tanzania." ESSD Studies and Monograph Series No. 20, World Bank, Washington, D.C.

and L. Pritchett. 1999. "Cents and Sociability: Household Income and Social Capital in Rural Tanzania." Economic Development and Cultural Change.

Paldam, M. and G.T. Svendsen. "An essay on social capital: looking for fire behind the smoke." European Journal of Political Economy 16: 339-66.

Putnam, R.D. 1993. Making Democracy Work: Civic Traditions in Modern Italy. Princeton: Princeton Univ. Press.

2000. Bowling Alone: The Collapse and Revival of American Community. New York: Simon and Schuster.

Rauch, J. E. 2001. "Business and Social Networks in International Trade." Journal of Economic Literature 39 (4): 1177-1203.

Rodrik, D. 1995. "Where Did All the Growth Go ? External Shocks, Social Conflict, and Growth Collapses." NBER Working Paper No. 6350. Cambridge, Ma.

Schiff, M. 1999. "Labor Market Integration in the Presence of Social Capital." Policy Research Working Paper No. 2222. World Bank. Washington, D.C.

. 2002. "Social Capital, Trade, and Optimal Migration Policy." European Journal of Political Economy (March).

Wildasin, D. E. 2000. "Labor-Market Integration, Investment in Risky Human Capital, and Fiscal Competition." American Economic Review 90 (1): 73-95.

Woolcock, M. and D. Narayan. 2000. "Social Capital: implications for development theory, research and policy." World Bank Research Observer 15 (2): 225-49.

World Bank. 2000. New Paths to Social Development. Community and Global Networks in Action. Social Development Department (ESSD Network). Washington, D.C.

Zak, P. J., Y. Feng and J. Kugler. 1998. "Immigration, fertility, and growth. 2002. Journal of Economic Dynamics and Control 26: 547-576.-

and S. Knack. 2001. “Trust and Growth.” Economic Journal 111: 295-321. 
Figure 1: Welfare (U)

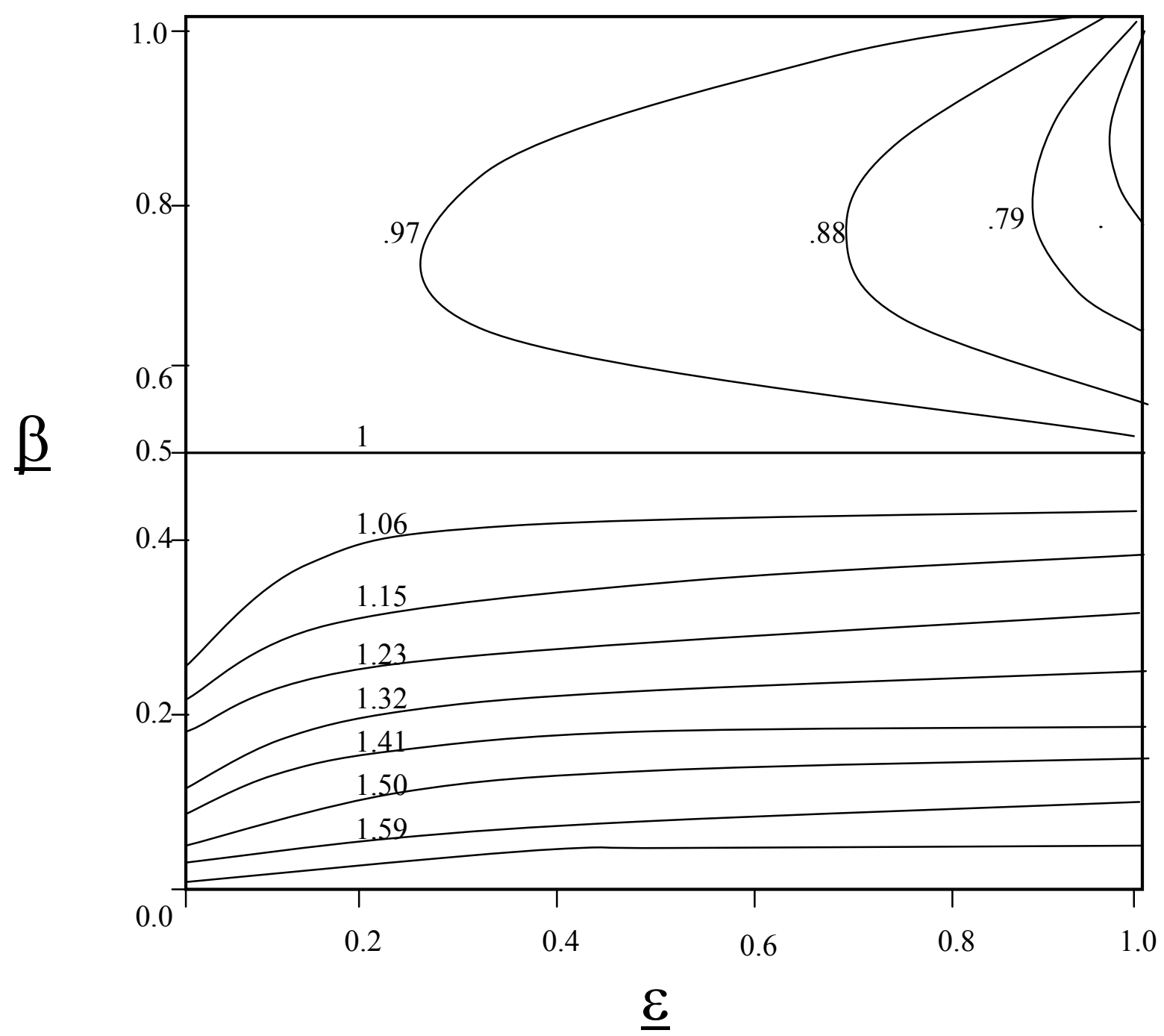

MSCHIFF

N:LMauricelSOCIAL $\backslash$ mobil20'.doc

December 5, 2003 11:48 AM 